\title{
Recent decline in body condition of departing Common Guillemots Uria aalge at Hornøya, North Norway
}

\author{
Robert T. Barrett
}

Barrett, R.T. 2010. Recent decline in body condition of departing Common Guillemots Uria aalge at Hornøya, North Norway. - Ornis Norvegica 33: 49-55.

Since 1980, there has been large variation and a recent decline in the mass and body condition of Common Guillemot Uria aalge chicks departing from the nest site in NE Norway. This may be related to deterioration in the feeding conditions off the colony and is alarming considering the critically endangered status of the species in Norway. To measure body condition, earlier studies have caught, weighed and measured guillemot chicks either while still on the breeding site or as they leave the colony. This study emphasises the importance of choosing and defining which method to use as they give different results.

Key words: Common Guillemot, Uria aalge, chick body condition

Robert T. Barrett, Dept. of Natural Sciences, Troms $\phi$ University Museum, NO-9037 Troms $\phi$, Norway. E-mail address:Rob.Barrett@uit.no

\section{INTRODUCTION}

Common Guillemots Uria aalge were once very common on mainland Norway and the population was estimated at 120-160 000 pairs in the 1960s (Brun 1969). Numbers have since declined severely (by $>95 \%$ ) as a result of egg harvesting, hunting, disturbance, drowning in fishing gear and food shortages to ca. 15000 pairs (in 2005, Barrett et al.2006). Some colonies are now so small that they are on the verge of extinction (Erikstad et al. 2007) and the Common Guillemot is classified as critically endangered in the Norwegian Red List (Kålås et al. 2006)

As a result, there is a need for an improved knowledge of their breeding ecology and population dynamics for a more precise modelling and better management of this threatened population (Erikstad et al. 2007). This is being addressed in the current national seabird monitoring programme (SEAPOP) in which Common Guillemots are one of the main target species in several key sites from Bjørnøya in the north to Runde in the south (Anker-Nilssen et al. 2005, www. seapop.no). One such key site is Hornøya $\left(72^{\circ}\right.$ $22^{\prime} \mathrm{N}, 31^{\circ} 10^{\prime} \mathrm{E}$ ) in East Finnmark on which ca. 8-9 000 pairs of common guillemots (in 2009, pers. obs.) breed.

Part of the monitoring effort on Hornøya has been to annually determine Common Guillemot chick growth and condition. Ideally, this can be done by repeat measurements of chicks of known age (e.g. Barrett et al. 1997, Hipfner \& Bryant 1999), but, as on most guillemot colonies, this is extremely difficult on Hornøya without undue disturbance of neighbouring pairs and subsequent predation of chicks and eggs by e.g. marauding gulls (Larus spp.). Instead, many studies have used 
single measurements of chicks as they leave the colony as proxies of interannual variation (e.g. in the Baltic Sea (Hedgren 1979), Eastern Canada (Burke \& Montevecchi 2008), Alaska (Piatt et al. 2007) and Shetland (Heubeck 2009)). Others have used single measurements of chicks caught on the breeding site and released back into the colony (Bryant et al. 1999, Wilhelm \& Storey 2004, Wanless et al. 2005). On Hornøya, both methods have been used and this study addresses the potential error of the latter method due to the age-dependent deceleration of mass gain or even mass recession prior to fledging (Barrett et al. 1997, Hipfner \& Bryant 1999, Barrett 2002).

\section{METHODS}

At Hornøya, the majority of Common Guillemots breeds on wide shelves at the south end of the cliff. Here, the cliff is ca. $25 \mathrm{~m}$ high and set 25-45 $\mathrm{m}$ back from the water's edge, and most chicks fail to reach the sea after launching themselves off the cliff. Instead they land in the vegetation below where they can be easily caught as they make their way down to the sea. Chicks depart from the colony in the evening and «night» and, as they approached the age and size of departure, close attention was paid for signs of chicks leaving the breeding sites. This was easily recognized by hectic activity and calling of adult birds and chicks on the sea under the colony. As experience showed that chicks would not jump from the cliff if there was too much wind (see also Greenwood 1964), visits were made to the main colony each evening during periods of calm weather and within a few days of the first chicks seen on the water. Departing chicks were caught, weighed $( \pm 2.5 \mathrm{~g})$, measured (wing length, from the carpal joint to the tip of the longest primary covert, $\pm 0.5 \mathrm{~mm}$ ) and ringed as they left the colony. Most chicks left the ledges between 2100 and 0000 hrs CEST (when the sun reaches its nadir at Hornøya), and the catching effort was targeted accordingly. In some seasons, chicks were caught on 2-3 different nights.

In some years, chicks were also caught, measured and ringed while still on the breeding site towards the end of the chick-rearing period. They were caught using a noose pole and released back onto the site after handling. Occasionally both methods were used in the same season enabling a direct comparison of both methods.

To compare measurements and masses of chicks leaving the colony in different seasons, only

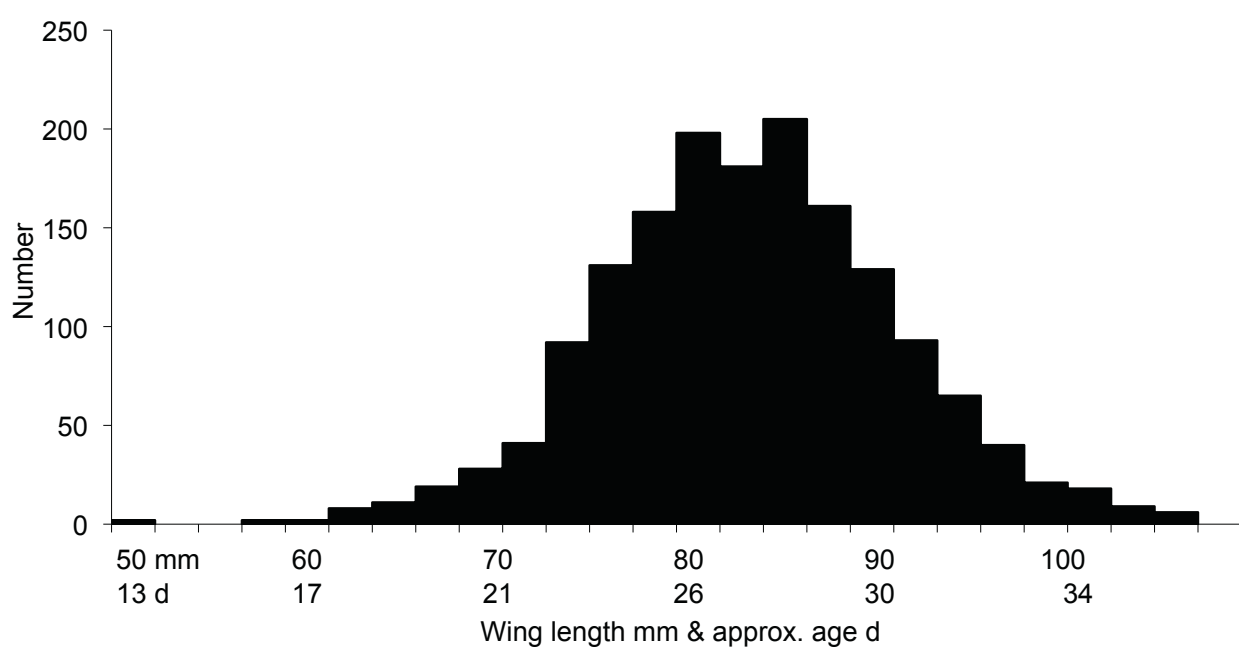

Figure 1. Distribution of wing length ( $\mathrm{mm})$ and approximate age (d) of 1601 Common Guillemot chicks caught under the breeding cliffs on Hornøya, North Norway in 1980-2009. 
data collected within $5 \mathrm{~d}$ of the start of fledging were used to avoid effects of seasonal variation in the measurements (Hedgren 1979). Chicks were aged using wing length and a linear relationship between wing length and age of chicks prior to fledging, and a mean of equations based on measurements of chicks made on Hornøya during an intensive study in 1990 (age $\mathrm{d}=-8.03$ $+0.42 *$ wing $\mathrm{mm}, \mathrm{r}^{2}=98 \%$ ) and 1991 (age $\mathrm{d}=$ $-8.68+0.43 *$ wing $\left.\mathrm{mm}, \mathrm{r}^{2}=985\right)($ Hedgren 1981 , Hatchwell 1991, Barrett et al. 1997)

Only 2\% (101 individuals) of the 1601 guillemot chicks caught on their way to sea had wing lengths of $<70 \mathrm{~mm}$ (Fig. 1), whereas 58\% (407 individuals) of 699 caught on the breeding shelf had wings $<70 \mathrm{~mm}$. Because there is normally little change in the chick mass once their wing lengths had reached $70 \mathrm{~mm}$ (Barrett et al. 1997) and to avoid bias resulting from the inclusion of younger birds in the samples of birds caught on the shelves, only birds with wings $\geq 70 \mathrm{~mm}$ were included in the comparison of these two groups. To reduce further any effect of age on body mass, a body condition index was calculated by dividing body mass by wing length (e.g. Wanless et al. 2005, Piatt et al. 2007).
Statistical tests were carried out using Mini$\operatorname{tab}^{\circledR} 15.1 .30$, and means are expressed \pm 1 standard error (SE). Trend curves were fitted using CurveExpert(C) 1.3.

\section{RESULTS}

\section{Measurements before and during fledging}

Direct comparisons between measurements of chicks caught on the breeding site and after fledging were possible in five seasons $(1983,1990$, 1997, 1998, 2004) and there was a clear tendency for chicks that had jumped from the cliff to be lighter and of lower body condition than those caught on the breeding site (Fig. 2). The differences were highly significant (students T-test, $\mathrm{p}<0.001)$ for all differences in body condition and significant $(\mathrm{p}<0.05)$ for mass in three $(1983$, 1998 and 2004) of the five years.

\section{Annual variation in fledging date and condition} Dates on which the first chicks were seen jumping from the breeding ledges varied considerably, ranging from 20 June (2002) to 12 July (1997) (Table 1). In 11 of the 17 years of records, chicks started to fledge between 5 and 10 July.

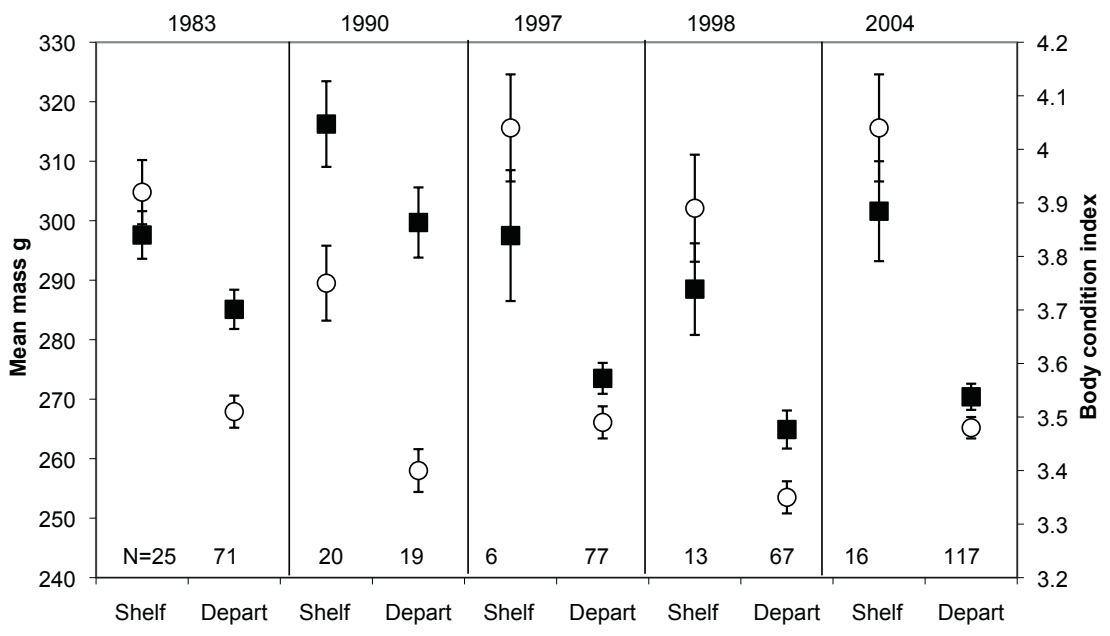

Figure 2. Mean mass (black squares $\pm 1 S E$ ) and body condition index (mass/wing length, circles \pm 1 SE) of Common Guillemot chicks with wings $\geq 70 \mathrm{~mm}$ caught on and after departing from the breeding shelf, Horn $\phi y a$, North Norway. Sample sizes are indicated. 
Table 1. Dates on which the first Common Guillemot chicks were seen fledging from breeding sites on Hornфya, 1980-2009.

$\begin{array}{lr}1980 & \text { 9 July } \\ 1982 & \text { 8 July } \\ 1983 & \text { 8 July } \\ 1989 & \text { 7 July } \\ 1990 & \text { 5 July } \\ 1993 & \text { 11 July } \\ 1997 & \text { 12 July } \\ 1999 & \text { 3 July } \\ 2000 & \text { 8 July } \\ 2001 & \text { 6 July } \\ 2002 & \text { 20 June } \\ 2004 & \text { 2 July } \\ 2005 & \text { 9 July } \\ 2006 & \text { 10 July } \\ 2007 & \text { 1 July } \\ 2008 & \text { 9 July } \\ 2009 & \text { 6 July }\end{array}$

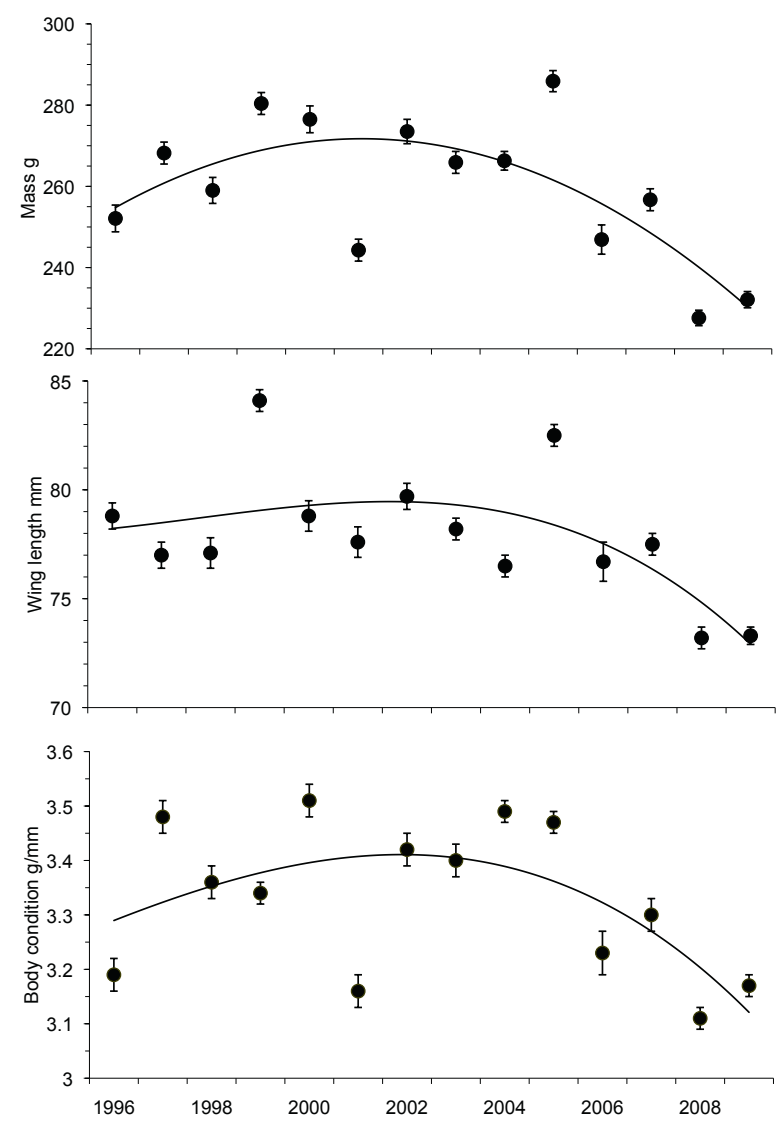

The mean mass, wing length and body condition of chicks caught as they left the breeding site varied significantly among 15 seasons in 1983 and 1996-2009 (Fig. 3, ANOVA: $\mathrm{F}_{14,1724}$ mass = 55.6, wing $=36.1$, condition $=27.6, \mathrm{p}<0.001$ in all cases). The data were best fitted by quadratic curves that showed a decline after 2000 (Fig. 3 ). Mean mass varied between $232.0 \pm 2.0 \mathrm{~g}$ (in 2009 ) to $285.9 \pm 2.6$ (in 2005), and wing length between $73.2 \pm 0.5 \mathrm{~mm}$ (in 2009) to $84.1 \pm 0.5$ (in 1999). The shortest wing recorded was $50 \mathrm{~mm}$ (weighing $192 \mathrm{~g}$ in 2008) and the lightest chicks were $150 \mathrm{~g}$ (wing $68 \mathrm{~mm}$ in 2001 and $63 \mathrm{~mm}$ in 2009). Three chicks with wings $98 \mathrm{~mm}$ (weighing 355,310 and $245 \mathrm{~g}$ ) were caught in 1983, 1999 and 2002 respectively, and the heaviest chick caught weighed $380 \mathrm{~g}$ (wing $96 \mathrm{~mm}$ in 1999).

The overall mean age of all chicks caught under the cliff was $24.7 \pm 0.1 \mathrm{~d}(\mathrm{~N}=1601)$ with $86 \%$
Figure 3. Variations in mass, wing length and body condition (mass/wing) of Common Guillemot chicks caught after jumping from the breeding site at Hornøya, North Norway, 1996-2009. Means \pm 1 SE. Sample sizes are indicated. (Curve equations - mass: $\left.y=\left(-2.6^{*} 10^{6}\right)+2637 x-0.66 x^{2}, r=0.72\right)$, wing: $y=$ $\left.\left(-3.6^{*} 10^{5}\right)+363 x-0.09 x^{2}, r=0.65\right)$, body condition: $y$ $\left.\left.=\left(-1.9 * 10^{4}\right)+19.3 x-0.001 x^{2}, r=0.61\right)\right)$.

being 21-28 d old (Fig 1). The youngest were approximately $13 \mathrm{~d}(\mathrm{~N}=2)$ and the oldest $33 \mathrm{~d}(\mathrm{~N}$ $=6)$. Chicks that fledged in 1999 and 2005 were older (ca. 27 d) and heavier (mean 280 and 286 $\mathrm{g}$ respectively) than in all other years, whereas those that fledged in 2001, 2008 and 2009 were lighter (mean 244, 228 and 232 g respectively) and in poorer condition (Fig. 3). 


\section{DISCUSSION}

Because the rate of increase in chick mass declines immediately prior to fledging, earlier studies have used the mass of chicks above a certain wing length as an index of chick condition (e.g. Bryant et al. 1999, Barrett 2002, Wanless et al. 2005, Heubeck 2009). This study shows that even when limiting sampling to large (in this case wings $\geq 70 \mathrm{~mm}$ ) individuals, chicks caught on the ledge may be $20-30 \mathrm{~g}(4-10 \%)$ heavier (with a corresponding difference in body condition) than those that have fledged (Fig. 2). This emphasises the need for consistency and a clear description of the choice of method in such long-term studies. A combination of the two methods, as used in my earlier analysis (Barrett 2002), should be avoided.

The 20-30 g difference in mass between chicks caught on the breeding sites and those caught under the cliff also suggests that chicks lose more mass prior to fledging than chick growth studies have previously suggested. Whereas published growth curves of known-aged common guillemot chicks (Birkhead 1977, Hedgren \& Linnman 1979, Barrett et al. 1997, Hipfner \& Bryant 1999) have no or very limited indication of mass recession prior to fledging, it is mentioned, albeit poorly documented, in earlier literature (Tuck 1960, Sealy 1973). The apparent absence of mass recession in regular controls of chicks on the breeding shelf is probably due to a) low sample numbers (chosen to avoid excess disturbance) and b) investigators weighing chicks every 2-3 d and thus failing to catch many in the last $1-2 \mathrm{~d}$ before fledging (see below). The advantage for a chick to lay down as much body reserves as possible before leaving the colony and thereby increase its chances of survival during the first days at sea (Hatch 1983) may be outweighed by the advantage gained from a minimal wing loading. As discussed in Øyan \& Anker-Nilssen (1986), the latter would maximise the length of glide path as the chick drops to the sea, and thereby reduce the otherwise potentially high rates of predation by e.g. large gulls (up to $17 \%$ in two studies, Greenwood 1964, Williams 1975).
Although variable, the overall mean masses of fledged Common Guillemot chicks on Hornøya were high and ranged between 22 and $27 \%$ of the mean adult body mass (on Hornøya $=1055 \pm$ $4 \mathrm{~g}, \mathrm{~N}=446$ ind., unpubl. data), well within the range of other studies (Hedgren \& Linnman 1979, Furness \& Barrett 1985, Harris \& Wanless 1988, Hatchwell 1991). Hornøya chicks were, however, slightly older (mean age $24.7 \mathrm{~d}$ ) when leaving the colony than chicks from more southern colonies (19-21 d, Birkhead 1977, Hedgren \& Linnman 1979, Hatchwell 1989). This may be an artefact of the method used to age the chicks, or more likely an indication that feeding conditions off Hornøya are so good that adults can prolong an efficient feeding of their chicks beyond the "normal" fledging age (Birkhead 1977). That the chicks that fledged in 2008 and 2009 had the shortest wings of all seasons (73.2 \pm 0.4 and 73.2 $\pm 0.5 \mathrm{~mm}$ respectively, Fig. 3) equivalent to an age of ca. $23 \mathrm{~d}$ suggests that feeding conditions were poorer than normal resulting in an earlier departure.

Despite the large interannual variations in the mass, wing length and body condition, exploratory analyses showed no relationship between any of these parameters with the timing of the breeding season (expressed as the date of first fledging), composition of the diet or load mass (unpubl. data). This is in contrast to an earlier study (Barrett 2002) where chick mass was positively related to the amount of sandeels Ammodytes sp. in the diet and, paradoxically, negatively related to estimates of the annual mean food load mass. However, no consideration is made in either study of the energetic content of the food, a factor that varies considerably with the size or reproductive status of a given fish species and that influences chick growth (Montevecchi \& Piatt 1984, Wanless et al. 2005). Furthermore, as the present study shows, my earlier analysis (Barrett 2002) was flawed in that it was based on a mixture of measurements of chicks caught on the ledge and caught when leaving the colony. Another important parameter that is not measured annually on Hornøya is the amount of food 
brought to the chicks. Feeding rates can vary considerably between years (e.g. Bryant et al. 1999, Heubeck 2009) and it is likely that the amount of food brought during the chicks' very active phase immediately prior to colony departure will strongly influence the departure mass (Wilhelm \& Storey 2004). Hatch (1983) showed that unfed, newly departed chicks lost a mean of $17.7 \mathrm{~g} / \mathrm{d}$ such that the 20-30 g difference shown here can be attributed to a reduction (or cessation?) of feeding on the last day(s) on the colony, as seen by Birkhead (1977) and Hatchwell (1991).

When considering other species in the colony, there is a close linear relationship between the mass $\left(r^{2}=0.51, p=0.003\right)$, size $\left(r^{2}=0.63, p<\right.$ $0.001)$ and body condition $\left(r^{2}=0.46, p=0.006\right)$ of fledged Common Guillemots and the overall breeding success (measured as no. of large chicks/nest at the end of the breeding season, Barrett 2007) of Black-legged Kittiwakes Rissa tridactyla on Hornøya. The reproductive success of both species have shown a negative tendency recently with Kittiwakes producing fewer and fewer chicks since 1980 (to near zero in 2008 and 2009) and Common Guillemot chicks fledging in gradually poorer condition since 2000 (Fig. 3, Barrett 2007, unpubl. data). This suggests there is a common environmental influence on the colony as a whole affecting the amount and/or quality of food available. Such a large-scale ecosystem change has been seen to affect Common Guillemots in the North Sea and the Baltic Sea (Wanless et al. 2005, Österblom et al. 2006).

The population of Common Guillemots on Hornøya has been increasing at a rate of $11 \%$ p.a. since an $80 \%$ collapse in numbers in 1987 and is one of very few, if not the only remaining viable colony of significant size on mainland Norway (the size of the population at what was once a large colony at nearby Syltefjord is unknown) (Erikstad et al 2007, Barrett et al. 2006). Much of this increase is considered to be due to the species' high degree of natal philopatry (Harris et al. 1996, pers. obs.), and given the possible consequences of poor fledging condition on local recruitment into the breeding population (Metcalfe \& Monaghan 2001, Morrison et al. 2009 - but see Harris et al. 1992), the recent decline in body mass of chicks leaving the colony is disturbing and should be addressed in the light of the critically endangered status of the Norwegian population of this species.

\section{ACKNOWLEDGEMENTS}

The Norwegian Coastal Administration is thanked for the use of the lighthouse on Hornøya as a base for the fieldwork. I am also grateful to Håkon Dahlen (Tromsø Univ. Museum) and Thierry Boulinier (CNRS Montpellier) and his many co-workers over the years for their help in catching, weighing and measuring the chicks, to Tycho Anker-Nilssen (NINA, Trondheim) for his comments on an early draft of the manuscript and to Robert Bergersen (Troms $\varnothing$ Univ. Museum) for correcting the Norwegian summary. The study was financed by Troms $\varnothing$ University Museum, the Norwegian National Monitoring Programme for Seabirds and the Norwegian SEAPOP programme (www.seapop.no).

\section{SAMMENDRAG}

\section{Nedgang i kroppskondisjon hos lomviunger på Hornøya, Nord-Norge.}

Mellom 1980 og 2009 var det stor variasjon og nedgang i vekt og kroppskondisjon hos lomviunger på de tider de forlot kolonien på Hornøya, Øst-Finnmark. Nedgangen var veldig tydelig etter 2000, og kan ha hatt sammenheng med næringsforholdene utenfor kolonien. Nedgangen er spesielt alarmerende siden arten er kritisk truet i Norge. I tidligere studier har ungenes kroppskondisjon blitt målt enten når de forlot kolonien, eller mens de ennå var på reirhyllene. Dette studiet understreker viktigheten av å skille disse metodene, da de gir forskjellig resultat. 


\section{REFERENCES}

Anker-Nilssen, T., Bustnes, J.O., Erikstad, K.E., Fauchald, P., Lorentsen, S.-H., Tveraa, T., Strøm, H.\& Barrett, R.T. 2005. SEAPOP. Et nasjonalt sjøfuglprogram for styrket beslutningsst $\varnothing t t e$ i marine områder. - Norwegian Institute for Nature Research, Rapport 1.

Barrett, R.T. 2002. Atlantic puffin Fratercula arctica and common guillemot Uria aalge chick diet and growth as indicators of fish stocks in the Barents Sea. - Marine Ecology Progress Series 230: 275-287.

Barrett,R.T.2007. Food web interactions in the southwestern Barents Sea: black-legged kittiwakes Rissa tridactyla respond negatively to an increase in herring Clupea harengus. - Marine Ecology Progress Series 349: 269-276.

Barrett R.T., Asheim M. \& Bakken, V. 1997. Ecological relationships between two sympatric congeric species, Common and Thick-billed Murres Uria aalge and $U$. lomvia breeding in the Barents Sea. - Canadian Journal of Zoology 75: 618-631.

Barrett,R.T.,Lorentsen,S.-H.\& Anker-Nilssen,T.2006. The status of breeding seabirds in mainland Norway. - Atlantic Seabirds 8: 97-126.

Birkhead, T. 1977. Adaptive significance of the nestling period of guillemots Uria aalge. - Ibis 119: 544-549.

Brun, E. 1969. Utbredelse og hekkebestand av lomvi (Uria aalge) i Norge. - Sterna 8: 209-244.

Bryant, R., Jones, I.L. \& Hipfner, J.M. 1999. Responses to changes in prey availability by common murres and thick-billed murres at the Gannet Islands, Labrador. - Canadian Journal of Zoology 77: 1278-1287.

Burke, C.M. \& Montevecchi, W.A. 2008. Fish and chicks: forage fish and chick success in co-existing auks. - Waterbirds 31: 372-284.

Erikstad, K.E, Reiertsen, T.K., Anker-Nilssen, T., Barrett, R.T., Lorentsen, S.-H., Strøm, H. \& Systad, G.H. 2007. Levedyktighetsanalyser for norske lomvibestander. - Norwegian Institute for Nature Research Rapport 240.

Furness, R.W.\& Barrett, R.T. 1985. The food requirements and ecological relationships of a seabird community in north Norway. - Ornis Scandinavica 16: 305-313.

Greenwood, J. 1964. The fledging of the guillemot Uria aalge with notes on the razorbill Alca torda.- Ibis 106: 469-481.

Harris, M.P., Halley, D.J. \& Wanless, S. 1992. The postfledging survival of young guillemots Uria aalge in relation to hatching date and growth. - Ibis 134: 335-339.

Harris, M.P., Halley, D.J. \& Wanless, S. 1996. Philopatry in the common guillemot Uria aalge. - Bird Study 43: 134-137.

Harris, M.P. \& Wanless, S. 1988.The breeding biology of guillemots Uria aalge on the Isle of May over a six year period. - Ibis 130: 172-192.

Hatch, S. 1983. The fledging of common and thick-billed murres on Middleton Island, Alaska. - Journal of Field Ornithology 54: 266-274.

Hatchwell, B.J. 1989. The effects of disturbance on the growth of young common guillemots Uria aalge. - Seabird 12: 35-39.

Hatchwell, B.J. 1991. The feeding ecology of young guillemots Uria aalge on Skomer Island, Wales. - Ibis 133: 153-161.

Hedgren, S. 1979. Seasonal variation in fledging weight of guillemots Uria aalge. - Ibis 121:356-361.

Hedgren, S. 1981. Effects of fledging weight and time of fledging on survival of guillemot Uria aalge chicks. - Ornis Scandinavica 12: 51-54.

Hedgren, S. \& Linnman, A. 1979. Growth of guillemot Uria aalge chicks in relation to time of hatching. - Ornis Scandinavica 10: 29-36.

Heubeck, M. 2009. Common guillemot Uria aalge chick diet and breeding performance at Sumburgh head, Shetland in 2007-2009, compared to 1990-91. Seabird 22: 9-18.

Hipfner, J.M. \& Bryant, R. 1999. Comparative breeding biology of guillemots Uria spp. and razorbills Alca torda at a colony in the northwest Atlantic. - Atlantic Seabirds 1: 121-134.

Kålås, J.A., Viken, Å. \& Bakken, T. (eds.). 2006. Norsk Rødliste 2006 - 2006 Norwegian Red List. Artsdatabanken, Trondheim, Norway.

Metcalfe, N.B. \& Monaghan, P. 2001. Compensation for a bad start: grow now or pay later? - Trends in Ecology and Evolution 16: 254-260.

Montevecchi, W.A. \& Piatt, J. 1984. Composition and energy contents of mature inshore spawning capelin (Mallotus villosus): implications for seabird predators. - Comparative Biochemistry and Physiology 78A: 15-20.

Morrison, K.W., Hipfner, J.M., Gjerdrum, C. \& Green, D.J. 2009. Wing length and mass at fledging predict local juvenile survival and age at first return in tufted puffins. - Condor 111: 433-441.

Piatt, J., Harding, A.M.A., Shultz, M., Speckman, S.G., van Pelt,T.I.,Drew, G. \& Kettle,A.B. 2007. Seabirds as indicators of marine food supplies: Cairns revisited. - Marine Ecology Progress Series 352: 221-234.

Sealy, S.G. 1973. Adaptive significance of post-hatching developmental patterns and growth rates in the Alcidae. - Ornis Scandinavica 4: 113-121.

Tuck, L.M. 1960. The Murres. Canadian Wildlife Series 1. Ottawa.

Wanless,S.,Harris, M.P., Redman,P.\& Speakman,J.R. 2005. Low energy values of fish as a probable cause of a major seabird breeding failure in the North Sea. - Marine Ecology Progress Series 294: 1-8.

Wilhelm, S.I. \& Storey, A.E. 2004. Temporal comparisons in feeding ecology and growth of young common guillemots Uria aalge.- Atlantic Seabirds 6:47-64.

Williams, A.J. 1975. Guillemot fledging and predation on Bear Island. - Ornis Scandinavica 6: 117-124.

Österblom, H., Casini, Olsson, O.\& Bignert, A. 2006. Fish, seabirds and trophic cascades in the Baltic Sea. - Marine Ecology Progress Series 323: 233-238.

Øyan, H.S. \& Anker-Nilssen, T. 1986. Allocation of growth in food-stressed Atlantic puffin chicks. - Auk 113: 830-841. 